\title{
FOMES ANNOSUS (FR.) CKE. ON RED PINE IN ONTARIO ${ }^{1}$ BY ERIK JORGENSEN
}

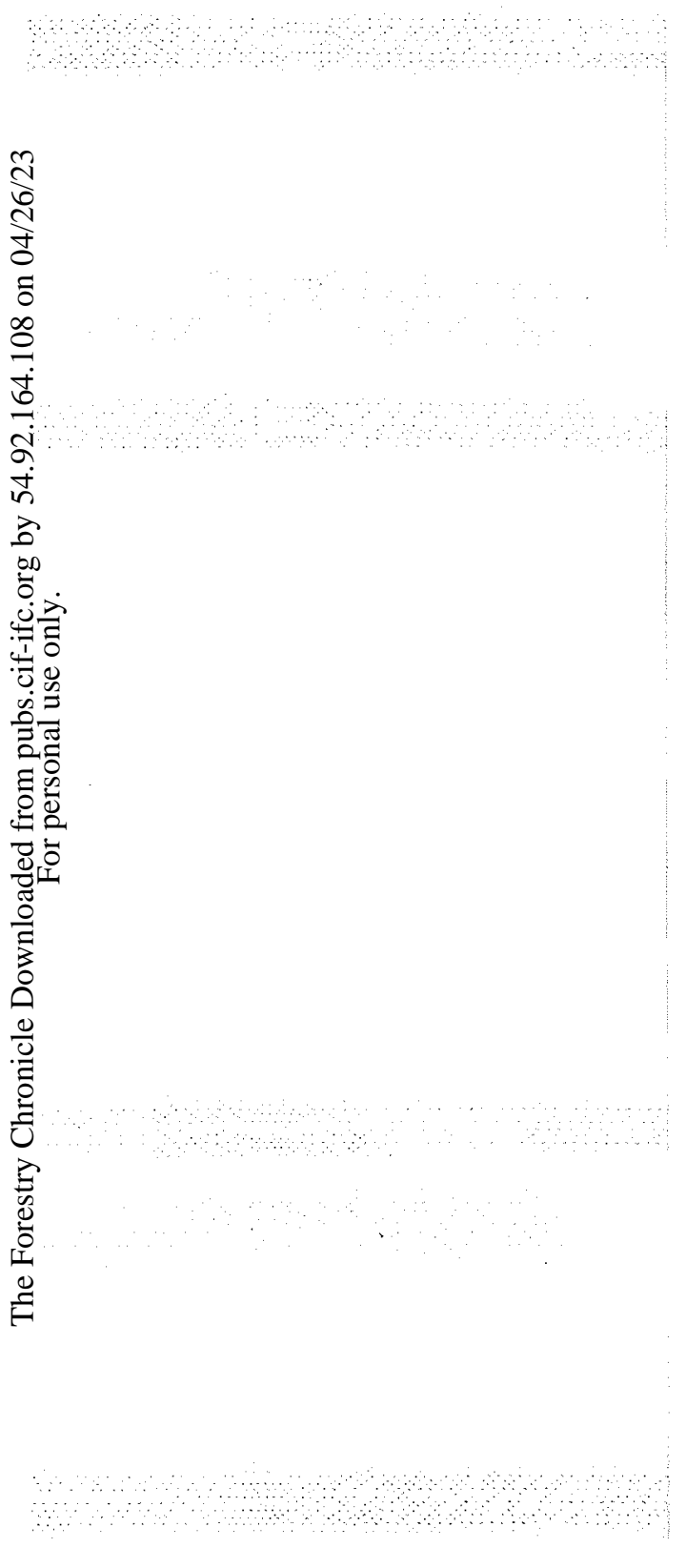

Born in Haderslev, Denmark. Master of Forestry 1946 from the Royal Veterinary and Agricultural College in Copenhagen, Denmark. Worked with the Danish Forestry Experiment Station, Springforbi, until entrance to military service in the fall of 1946; after two years of service in the Danish Army further work for the Danish Forestry Experiment Station, and locum work for the Assistant in Silviculture at the Royal Veterinary and Agricultural College; July 1, 1949, appointed Assistant in Forest Pathology at the Department of Plant Pathology of the Royal Veterinary and Agricultural College; in 1953 appointed Amanuensis at the same Department; from October 1953 also Project Leader at the Danish Forestry Experiment Station, Springforbi. In April, 1955, appointed Research Officer in charge of plantation diseases in Ontario at the Forest Pathology Laboratory, Southern Research Station, Maple, Ontario.

Root and butt rot, caused by Fomes annosus (Fr.) Cke., is one of the most important forest tree diseases in coniferous plantations of Europe $(5,8,9,10$, $11,12,13,15)$. The fungus attacks both coniferous and deciduous trees and its host range includes practically all woody plants from Calluna vulgaris and Rosa rugosa to Fagus sylvatica, Quercus spp., and Pinus spp. (15).

Its attack on various species of Picea and Pinus is economically the most important. On deciduous trees it is of interest to forestry only on very poor coils, especially where these trees are subsequently grown on cutover coniferous plantations in which infection was present. From a scientific point of view, the occurrence of $F$. annosus on roots of deciduous trees is very important owing to the fact that the fungus will often infect a coniferous crop from stumps of deciduous trees. Infection takes place through spore germination on freshly cut stump surfaces, growth of the fungus through the stump roots, and subsequent infection of the root systems of neighboring trees through root grafts or through connections between the two root systems $(10,11,12)$.

There are probably also other means of infection, such as by spores carried in rainwater to dying mycorrhizal rootlets, through wounds, or by means of spores carried by root-attacking insects (15). Even the possibility of infections due to growth of the fungus in the soil or in the litter layer cannot be overlooked (15).

Thinning seems, in general, to increase the disease in the stand as a whole $(5,6,13,15)$; in some cases, different soil types apparently have the same effect (12). The disease is increased in forest stands built up by artificial cultural methods on former arable or waste areas, so that the incidence of the disease is particularly high in coniferous plantations. Because of the recent origin of plantations in North America compared with those in Europe, it may be expected that $F$. annosus in this country will become increasingly important both with the advancing age of the plantations and with the increasing number of thinnings $(1,4,14,15)$. The fungus is widely distributed in Canada and United States, where it has been recorded in the West and in the East, both as a parasite and a saprophyte on coniferous trees $(1,2,3,4,6,7,14)$.

${ }^{2}$ Contribution No: 238, Forest Biology Division, Science Service, Department of Agriculture, Ottawa. 
The following, nevertheless, appears to be the first record of Fomes annosus from Ontario:

In May, 1955, fruit bodies of the fungus were obtained on the stumps of dead trees in a 42-year-old stand of Pinus resinosa Ait. in Compartment 27 of the plantation at St. Williams, Ontario (Plate I, Fig. 1, 2, 3). The identity of the fungus was verified through a heavy formation of the characteristic conidiophores on pieces of roots from a dying tree, obtained by the following method recommended by Rishbeth (10):

Pieces of root were rinsed very carefully with soap and water; then, each piece was cut in two longitudinally with a sterile knife, wrapped in damp newspaper, and placed in a moist chamber for 6 days.

Furthermore, a pure culture of the fungus was obtained.

The red pine stand, which had been thinned for the first time 26 years ago following damage by an ice storm, was thinned again during the winter of 1954-55 when it was observed that a number of trees in two sections of the stand were dying off. The occurrence of $F$. annosus at St. Williams was very similar to that in Europe, where the formation of "Fomes-holes", or openings in the stand where trees have been killed by the fungus, is the most typical indication of its presence.

The specimens from St. Williams are incorporated in the mycological herbarium of the Forest Pathology Laboratory at Maple as F.P.T. No. 2646 and No. 2647.

\section{REPERENCES}

1. BAXTER, D. V., 1952. Pathology in forest practice. John Wiley and Sons, Inc., New York.

2. BAXTER, D. V., 1941. Some resupinate polypores from the region of the Great Lakes. XII Papers Mich. Acad. Sci. Arts and Lett. 26:107-121.

3. BIER, J. E., 1949. Some common tree diseases of British Columbia. Can. Dept. Agr. Ottaw2.

4. BOYCE, J. S., 1948 Forest pathology. McGraw-Hill Book Company, Inc., New York.

5. HENRIKSEN, H. A. and JORGENSEN, ERIK, 1953. Fomes annosus attack in relation to grade of thinning. Det Forstlige Forsogsvaesen i Danmark, 21:215-251.

6. HEPTING, G. H. and DOWNS, A. A., 1944. Root and butt rot in planted white pine at Biltmore, North Carolina. J. Forestry, 42:119-123.

7. OVERHOLTS, L. O., 1953. The Polyporaceae of the United States, Alaska and Canada. University of Michigan Press, Ann Arbor, Mich.

8. PEACE, T. R., 1938. Butt rot of conifers in Great Britain. Quart. J. Forestry, 32:81-104.

9. RENNERFELT, E., 1952. On root-rot attack on Scots pine. Medd. fron Statens Skogsforskningsinstitut, $41: 1-44$.

10. RISHBETH, J., 1950. Observations on the biology of Fomes annoszs, with particular reference to East Anglian pine plantations. I. The outbreaks of disease and ecological status of the fungus. Ann. Bot. 14 (n.s.):365-383.

11. RISHBETH, J., 1951. Observations on the biology of Fomes annosus, with particular reference to East Anglian pine plantations. II. Spore production, stump infection, and saprophytic activity in stumps. Ann. Bot. 15(n.s.):1-21.

12. RISHBETH, J., 1951. Observations on the biology of Fomes annosis, with particular reference to East Anglian pine plantations. III. Natural and experimental infection of pines, and some factors affecting severity of the disease. Ann. Bot. 15(n.s.):221-246.

13. ROHMEDER, E., 1937. Die Stammfaule (Wurzelfaule and Wundfaule) der Fichtenbestockung. Mitt. aus der Landesforstverwaltung Bayerns, Munchen

14. WELCH, D. S. and STONE, E. L., 1953. Fomes annosus (Fr.) Cke. in coniferous plantations in New York State. Plant Disease Reporter, 37:247-248.

15. Report of special conference on root-and butt-rots of forest trees. Wageningen. 22-26 July, 1954. (V2rious papers). International Union of Forest Research Organizations. 